\title{
Anti-apoptotic Effects of Red Ginseng on Oxidative Stress Induced by Hydrogen Peroxide in SK-N-SH Cells
}

\author{
Eun-Hye Kim ${ }^{1 \#}$, Mi-Jeong Lee ${ }^{1 \#}$, In-Hye Kim ${ }^{1}$, Suhkneung Pyo ${ }^{1}$, Kwang-Tae Choi ${ }^{2}$, \\ and Dong-Kwon Rhee ${ }^{1^{*}}$ \\ ${ }^{1}$ School of Pharmacy, Sungkyunkwan University, Suwon 440-746, Korea \\ ${ }^{2}$ The Korean Society of Ginseng, Seoul 137-070, Korea
}

Ginseng (Panax ginseng C.A. Meyer) has been shown to have anti-stress effects in animal studies. However, most studies have only managed to detect altered levels of biomarkers or enzymes in blood or tissue, and the actual molecular mechanisms by which ginseng exerts these effects remain unknown. In this study, the anti-oxidative effect of Korean red ginseng (KRG) was examined in human SK-N-SH neuroblastoma cells. Incubation of SK-N-SH cells with the oxidative stressor hydrogen peroxide resulted in significant induction of cell death. In contrast, pre-treatment of cells with KRG decreased cell death significantly. To elucidate underlying mechanisms by which KRG inhibited cell death, the expression of apoptosis-related proteins was examined by Western blot analysis. KRG pre-treatment decreased the expression of the pro-apoptotic gene caspase-3, whereas it increased expression of the anti-apoptotic gene Bcl-2. Consistent with this, immunoblot analysis showed that pre-treatment of the SK-N-SH cells with KRG inhibited expression of the pro-inflammatory gene cyclooxygenase 2 (COX-2). RT-PCR analysis revealed that the repression of COX-2 expression by KRG pre-treatment occurred at the mRNA level. Taken together, our data indicate that KRG can protect against oxidative stress-induced neuronal cell death by repressing genes that mediate apoptosis and inflammation.

Keywords: Red ginseng, Apoptosis, Anti-oxidative stress, SK-N-SH cells

\section{INTRODUCTION}

Ginseng (Panax ginseng C. A. Meyer) has been used medicinally in East Asian countries. It is currently one of the most widely taken herbal products, used as an alternative/supplementary medicine with anti-cancer, anti-diabetic, and anti-inflammatory activities. The major active ingredients of ginseng are recognized as ginsenosides [1]. Korean red ginseng (KRG) is produced by steaming, and then drying, fresh ginseng. The steaming process hydrolyzes and converts ginsenosides into other types of ginsenosides, which include red ginseng-specific anti-cancer compounds (ginsenoside-Rh2, -Rh4, -Rs3, -Rs4, -Rg5), and the anti-metastasis and vasodilation compound ginsenosideRg3. The anti-oxidative and anti-cancer activities of KRG seem to be superior to those of white ginseng [1]. Stress decreases physical and mental tolerances and disturbs homeostasis, and subsequently causes diseases or aggravates existing illness. Of the many types of stresses, oxidative stress induces numerous diseases and contributes to aging and brain damage. (c) This is an Open Access article distributed under the terms of the Creative Commons Attribution Non-Commercial License (http://creativecommons.org/licenses/by-nc/3.0/) which permits unrestricted non-commercial use, distribution, and reproduction in any medium, provided the original work is properly cited.
Received 24 Mar. 2010, Revised 29 Mar. 2010, Accepted 30 Mar. 2010

*Corresponding author

E-mail: dkrhee@skku.edu

Tel: +82-31-290-7707, Fax: +82-31-290-7727

\#These two authors contributed equally to this article. 
Therefore, reduction of stress is important for the prevention of diseases and improvement of quality of life. Although many studies have demonstrated the reduction of stress or its physiological indicators in animals by administration of ginseng or several of its selected components, these studies are limited to describing the levels of specific factors that are altered, such as hormones and enzymes in blood or tissue. On a treadmill running test, ginseng administration significantly increased endurance time to exhaustion, and concomitantly increased the basal level of ACTH and corticosteroids [2]. Administration of ginseng extract to human subjects significantly increased catalase and superoxide dismutase levels after prolonged running and decreased malondialdehyde levels [3]. Ginseng extract administration was also shown to prevent oxidative damage to rat muscle in response to intense exercise [4]. Ginsenoside Rg1 was shown to decrease brain damage caused by the oxidative stress-inducing agent 1-methyl-4-phenyl-1, 2, 3, 6-tetrahydropyridine [5]. Ginseng suppressed adrenal gland weight gain and gastric ulcer formation, and was more effective against long-term stress than short-term stress. Moreover, ginseng effectively maintained levels of plasma glucose, triglycerides, cholesterol, creatine kinase, and corticosterone after exposure to stress [6]. After immobilization stress, administration of ginseng total saponin, $\mathrm{Rg} 3$, and $\mathrm{Rb} 1$ was shown to cause a decrease in polyamine component putrescine, a stress indicator [7], and administration of ginseng total saponin, ginsenoside $\mathrm{Rb} 2, \mathrm{Rg} 1$, and $\mathrm{Rd}$ decreased plasma levels of IL-6, which was induced by immobilization stress [8]. Ginseng total saponin was also shown to protect against oxidative stress induced by cyclophosphamide in mouse bone marrow cells and peripheral lymphocytes [9]. Consistent with anti-stress effects observed in the swim test $[10,11]$ or cold stress swim test $[10,11]$, these reports demonstrate classical anti-stress responses.

Despite these findings, a limited number of studies have been performed in brain and neuronal cells. Ginseng extract or ginsenosides have been shown to protect astrocytes grown in primary culture $[12,13]$. In other studies, ginseng total saponin protected human neuroblastoma cells from cyclosporine A-induced calcineurin inhibition and tau hyperphosphorylation [14], and improved depression caused by forced swim and chronic stress [15]. Ginsenoside Rb1 was shown to repress cell death induced by 6-hydroxydopamine in SH-SY5Y neuroblastoma cells [16], and protected dopaminergic cells from oxidative stress $[17,18]$. Other ginsenosides have been shown to be protective: for neuronal cells exposed to kainic acid- and glutamate-induced excitotoxicity $[17,19]$, for PC12 pheochromocytoma cells exposed to glutamate-induced neurotoxicity [20], and for hippocampal neurons exposed to oxygen-glucose depleted condition [21]. However, the mechanism by which red ginseng decreases or modulates apoptosis induced by oxidative stress in brain remains unknown. Therefore, we investigated the antioxidant and anti-apoptosis activity of KRG in neuronal cells.

\section{MATERIALS AND METHODS}

\section{Mice, eukaryotic cells, antibodies, and primers}

Four week old male ICR mice were purchased from Orient (Seoul, Korea), and kept for 1 week in the animal room at the College of Pharmacy, Sungkyunkwan University, for adaptation. Human neuroblastoma SKN-SH cells (HTB-11; American Type Culture Collection, Rockville, MD, USA) were cultured in RPMI 1640 media (Lonza, Walkersville, MD, USA) containing $10 \%$ fetal bovine serum, $1 \% 10,000 \mathrm{U}$ penicillin/ $\mathrm{mL}, 10,000 \mu \mathrm{g}$ streptomycin/mL, $1 \mathrm{mM}$ HEPES, $1 \mathrm{mM}$ sodium pyruvate, $4.5 \mathrm{~g} / \mathrm{L}$ glucose, $1.5 \mathrm{~g} / \mathrm{L}$ bicarbonate, $2 \mathrm{mM}$ L-glutamine at $37^{\circ} \mathrm{C}, 5 \% \mathrm{CO}_{2}$. Prior to experiments, cells were seeded on Petri-dishes and incubated for more than 12 hours. Antibodies raised against Bcl2 (Santa Cruz Biotechnology, Santa Cruz, CA, USA), Caspase-3 (Cell Signaling Technology, Danvers, MA, USA), and NF- $\kappa$ B p50 (Upstate Biotechnology, Lake Placid, NY, USA) were purchased.

\section{Red ginseng extract treatment}

Red ginseng extract (KRG extract from Korea Ginseng Corporation, Daejeon, Korea) was diluted with sterile phosphate buffered saline (PBS) to make $10 \mathrm{mg} /$ $\mathrm{mL}$ of stock solution. Prior to experiment, the KRG stock was further diluted to $1 \mathrm{mg} / \mathrm{mL}$ with RPMI 1640 media and filtered through $0.22 \mu \mathrm{m}$ filter (Nalgene, Rochester, NY, USA).

\section{MTT assay}

Cell viability was determined by the MTT assay as described [22]. Briefly, $1 \times 10^{4}$ SK-N-SH cells in $100 \mu \mathrm{L}$ of RPMI 1640 media were cultured in 96 well plates overnight. After overnight incubation, the cells were treated with $1 \mathrm{mg} / \mathrm{mL}$ of KRG (for $48 \mathrm{~h}$ ) (cells in RPMI 1640 media alone were used as a control). After treatment with $\mathrm{H}_{2} \mathrm{O}_{2}(0.5 \mathrm{mM}$ for $1,2 \mathrm{~h})$, cells were washed with PBS and incubated with $100 \mu \mathrm{L}$ of RPMI 1640 
and $25 \mu \mathrm{L}$ of MTT solution $(2 \mathrm{mg} / \mathrm{mL}$ ) followed by incubation at $37^{\circ} \mathrm{C}, 5 \% \mathrm{CO}_{2}$ for 4 hours. The supernatant was removed and $150 \mu \mathrm{L}$ of dimethyl sulfoxide (DMSO) was added into the well. Subsequently, purple formazan was dissolved completely in DMSO for 15 minutes, and optical density at $540 \mathrm{~nm}$ was determined by ELISA reader. Three samples were used for each condition.

\section{Western blot analysis}

Cells treated with $\mathrm{KRG}$ and $\mathrm{H}_{2} \mathrm{O}_{2}$ were washed with PBS, re-suspended in $1 \mathrm{~mL}$ of PBS, and harvested by centrifugation at $12,000 \mathrm{rpm}, 4^{\circ} \mathrm{C}$ for 15 minutes. The cell pellet was re-suspended in $200 \mu \mathrm{L}$ of lysis buffer (Tris $0.6 \mathrm{~g}, \mathrm{NP}-401 \mathrm{~mL}, \mathrm{NaCl} 0.88 \mathrm{~g}$, sodium deoxycholate $0.5 \mathrm{~g}$, sodium dodecyl sulfate [SDS] $0.01 \mathrm{~g} / 100$ $\mathrm{mL}$, and $20 \mu \mathrm{L}$ of $100 \mathrm{mM}$ phenylmethylsulphonyl fluoride) and subjected to sonication. The sonicated sample was centrifuged at $12,000 \mathrm{rpm}, 4^{\circ} \mathrm{C}$ for 15 minutes, and supernatant was harvested for protein determination by the Bradford assay. For Western blot analysis, 30-40 $\mu \mathrm{g}$ of protein was resolved by SDS-polyacrylamide gel electrophoresis on $10 \%$ or $15 \%$ gels. After electrophoresis, proteins were transferred to a PVDF membrane (Millipore, Bedford, MA, USA). To block non-specific binding of proteins to membrane, the membrane was treated with blocking buffer $(5 \%$ skim milk in $20 \mathrm{mM}$ Tris-HCl, $150 \mathrm{mM} \mathrm{NaCl}, 0.1 \%$ Tween 20 [TTBS]) for $>5$ hours with shaking, followed by washing with TTBS three times. Subsequently, proteins were incubated with primary antibody for $>5$ hours at room temperature. The membrane was washed with TTBS three times, and incubated with secondary antibody (HRP-conjugated anti-IgG antibody) for 1 hour at room temperature. Subsequently, the membrane was washed with TTBS three times and exposed to detection reagent (TMB; SigmaALdrich, St Louis, MO, USA); the amount of each protein was quantitated by the band intensity.

\section{mRNA level determination}

To isolate total RNA, $1.5 \times 10^{6} \mathrm{SK}-\mathrm{N}-\mathrm{SH}$ cells were plated in a $60 \mathrm{mM}$ culture dish and treated with KRG and $\mathrm{H}_{2} \mathrm{O}_{2}$. After treatment, the cells were washed with
PBS and $1 \mathrm{~mL}$ of Trizol reagent (Invitrogen, Carlsbad, CA, USA) was added to dissolve the cells. Subsequently, total RNA was isolated according to the manufacturer's suggestion. The amount of isolated RNA was determined by UV spectrophotometric absorbance at $260 \mathrm{~nm}$. One $\mu \mathrm{g}$ of isolated RNA was converted to cDNA using the M-MLV Reverse Transcriptase kit (RexGene Biotech, Cheongwon, Korea) according to the manufacturer's suggestion. PCR was performed using a thermal cycler (GeneAmp PCR system 2700; Applied Biosystems, Foster City, CA, USA), with $\beta$-actin serving as a control. PCR was performed for 35 cycles with pre-denaturation at $95^{\circ} \mathrm{C}$ for 10 minutes, and denaturation at $95^{\circ} \mathrm{C}$ for 30 seconds, annealing at $55^{\circ} \mathrm{C}$ for 30 seconds, extension at $75^{\circ} \mathrm{C}$ for 30 seconds followed by preservation at $4^{\circ} \mathrm{C}$.

\section{Agarose gel electrophoresis}

To analyze nucleic acid, electrophoresis was performed using $1 \%$ agarose gel with $1 \mathrm{~Kb}$ Plus Marker (Bioneer, Daejeon, Korea) as a molecular weight marker.

\section{Statistical analysis}

The results are expressed as the mean \pm standard deviation. The statistical significance of differences between two groups was assessed using the Dunett's $t$-test in the ANOVA program. Probability values of less than 0.05 were considered significant $\left({ }^{*} p<0.05,{ }^{* *} p<0.01\right.$, $* * * p<0.001)$.

\section{RESULTS AND DISCUSSION}

\section{Effect of KRG on cell viability}

The effect of KRG on the viability of neuronal cells has not been previously reported. We therefore tested various concentrations of KRG on SK-N-SH cells to determine if a certain concentration would affect cell viability. Incubation of various concentrations of KRG with SK-N-SH cells for 24 hours revealed that cell viability was not affected by $<1 \mathrm{mg} / \mathrm{mL}$ of $\mathrm{KRG}$, but was decreased by $>5 \mathrm{mg} / \mathrm{mL}$ of KRG (Fig. 1).

Table 1. List of primers and PCR product size used for RT-PCR

\begin{tabular}{cl}
\hline Genes & \multicolumn{1}{c}{ Primer sequence (5'-3') } \\
\hline COX-2 & Forward: act cac tca gtt tgt tga gtc att c \\
$($ RT-PCR $)$ & Reverse: ttt gat tag tac tgt agg gtt aat g \\
\hline \multirow{2}{*}{-actin } & Forward: tgg aat cct gtg gca tcc atg aaa c \\
& Reverse: taa aac gca get cag taa cag tcg g
\end{tabular}

COX-2, cyclooxygenase 2. 


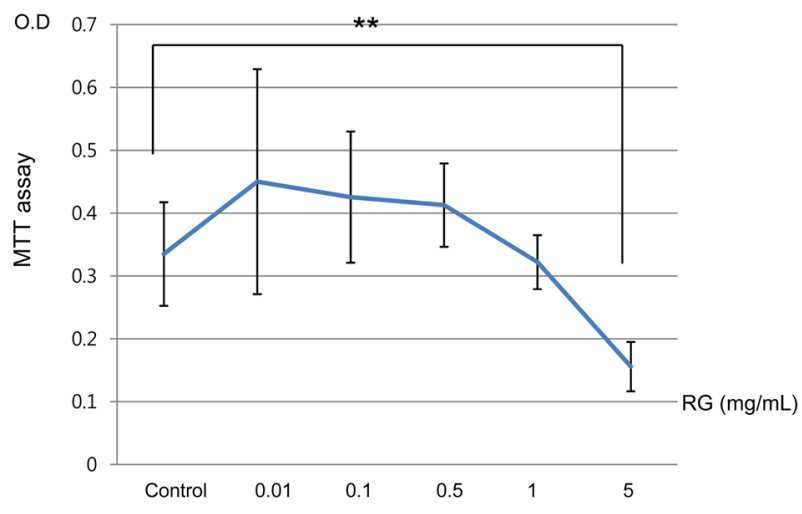

Fig. 1. Effects of Korean red ginseng (KRG) on cytotoxicity of SK-N-SH cells. SK-N-SH cells $\left(5 \times 10^{4}\right.$ cells) were pre-treated with KRG extract (0.01, $0.1,0.5,1$, and $5 \mathrm{mg} / \mathrm{mL}$ ) for 24 hours. Cytotoxicity of the SK-N-SH cells was determined by MTT assay. ${ }^{* *} p<0.01 ; O . D$, optical density; RG, red ginseng.

Therefore, $1 \mathrm{mg} / \mathrm{mL}$ of $\mathrm{KRG}$ was used in subsequent experiments.

\section{Anti-oxidative effect of KRG}

Due to the ability of KRG to scavenge free radicals and thereby potentially interfere with the oxidative stress effect of $\mathrm{H}_{2} \mathrm{O}_{2}$, cells pre-treated with $\mathrm{KRG}$ were washed with new media prior to addition of hydrogen peroxide. Moreover, a preliminary experiment showed that a 48 hour pre-treatment with KRG was more protective than 24 hour pre-treatment against $\mathrm{H}_{2} \mathrm{O}_{2}$ induced damage.

The ability of KRG to modulate $\mathrm{H}_{2} \mathrm{O}_{2}$-mediated toxicity was examined. When SK-N-SH cells were exposed to $0.5 \mathrm{mM} \mathrm{H}_{2} \mathrm{O}_{2}$ alone, cell viability was decreased, as compared to the untreated control (Fig. 2). In contrast, when the cells were pre-treated for 48 hours with $1 \mathrm{mg} /$ $\mathrm{mL} \mathrm{KRG}$, the viability of the cells was significantly higher than the non-pre-treated control group (35\% and $28 \%$, after 1 hour and 2 hours of exposure to $\mathrm{H}_{2} \mathrm{O}_{2}$, respectively) (Fig. 2).

\section{Expression of caspase-3 and Bcl-2 genes after oxi- dative stress}

The increase in SK-N-SH cell viability by pre-treatment with KRG before exposure to $\mathrm{H}_{2} \mathrm{O}_{2}$ suggests that KRG might modulate expression of cell death-related genes. To examine this possibility, expression levels of the pro-apoptotic protein caspase-3, the anti-apoptotic protein Bcl-2, and inflammation-related protein NF$\kappa \mathrm{B}$ were determined by Western blot analysis. Results showed that after exposure to $\mathrm{H}_{2} \mathrm{O}_{2}$, expression levels of caspase- 3 were increased by $27.6 \%$, and NF- $\kappa \mathrm{B}$

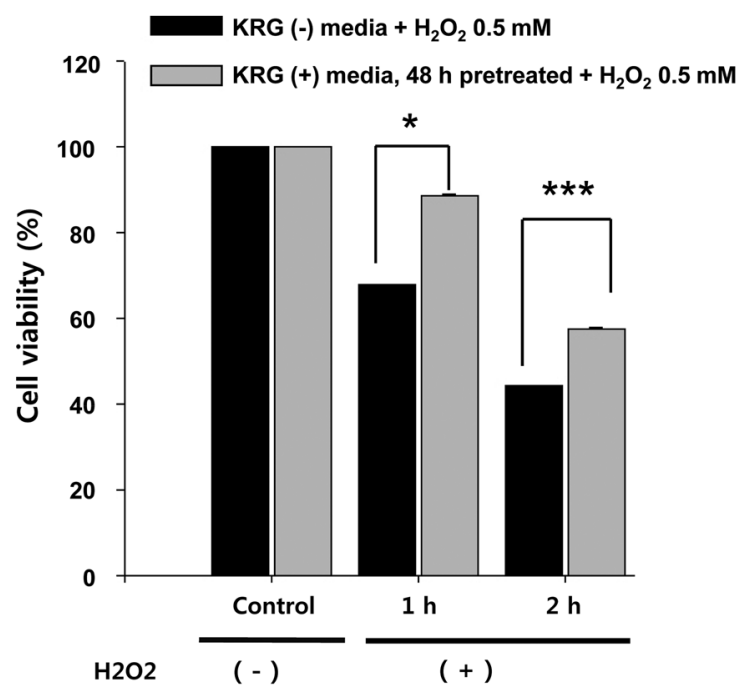

Fig. 2. Effects of Korean red ginseng (KRG) pre-treatment on the viability of $\mathrm{H}_{2} \mathrm{O}_{2}$-exposed SK-N-SH cells. SK-N-SH cells $\left(5 \times 10^{4}\right.$ cells) were pretreated with $1 \mathrm{mg} / \mathrm{mL}$ KRG extract for 48 hours; cells were then washed with fresh media and exposed to $0.5 \mathrm{mM} \mathrm{H}_{2} \mathrm{O}_{2}$ for 1 or 2 hours. Cytotoxicity was determined using the MTT assay. ${ }^{*} p<0.05$; ${ }^{* * *} p<0.001$.

and Bcl-2 genes were increased by $1.75 \%$ and $1.26 \%$, respectively, compared to untreated SK-N-SH cells. However, pre-treatment with KRG resulted in a $14.4 \%$ decrease in caspase- 3 expression, even after exposure to oxidative stress; NF- $\mathrm{kB}$ and Bcl-2 levels were induced by $33.57 \%$ and $60.8 \%$, respectively (Fig. 3). To confirm inhibition of caspase-3 expression by KRG, the experiment was repeated twice and the same results were observed each time (data not shown).

\section{NF-KB gene expression after oxidative stress}

To confirm the anti-oxidative stress effect of KRG, time-dependent modulation of NF- $\mathrm{kB}$ protein expression by KRG was determined by Western blot. After exposure of SK-N-SH cells to $0.5 \mathrm{mM} \mathrm{H}_{2} \mathrm{O}_{2}$ for 1 hour or 2 hours, expression of NF- $\kappa \mathrm{B}$ protein was increased by $79 \%$ or $169.8 \%$, respectively, compared to untreated control cells. However, pre-treatment with $1 \mathrm{mg} / \mathrm{mL}$ of KRG for 48 hours limited NF- $\kappa B$ induction to $23.4 \%$ or $31.2 \%$ at the 1 hour and 2 hours points, respectively (Fig. 4). These results demonstrate that pre-treatment with KRG significantly repressed (by three-fold) the induction of NF- $\mathrm{kB}$ expression by exposure to oxidative stress (Fig. 4). It must be noted that our Western blot analysis demonstrates changes in NF- $\mathrm{KB}$ expression levels, not NF- $\mathrm{KB}$ activity. Further experiments are required to determine how $\mathrm{KRG}$ treatment induces NF- $\mathrm{kB}$ levels. 


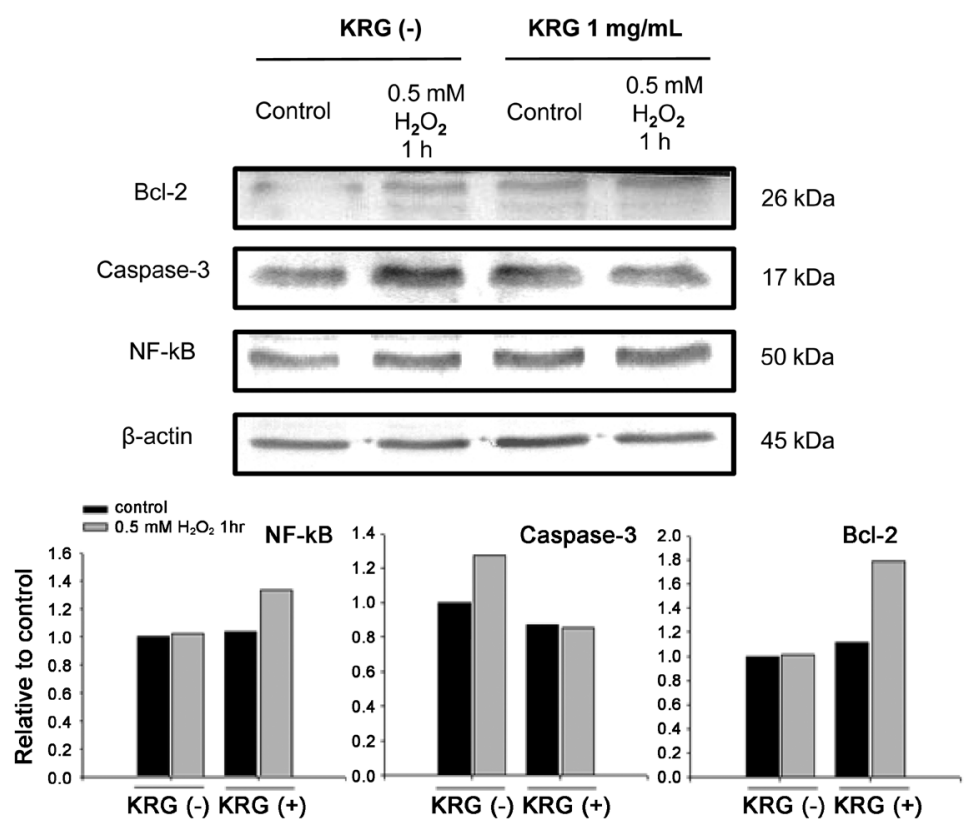

Fig. 3. Effects of Korean red ginseng (KRG) pre-treatment on the expression of apoptosis-related proteins in $\mathrm{H}_{2} \mathrm{O}_{2}$-exposed SK-N-SH cells. SK-N-SH cells $\left(5 \times 10^{4}\right.$ cells) were pre-treated with $1 \mathrm{mg} / \mathrm{mL} \mathrm{KRG}$ extract for 48 hours; cells were then washed with fresh media and exposed to $0.5 \mathrm{mM} \mathrm{H}_{2} \mathrm{O}_{2}$ for 1 hour. Protein levels were determined by Western blot using specific antibodies.

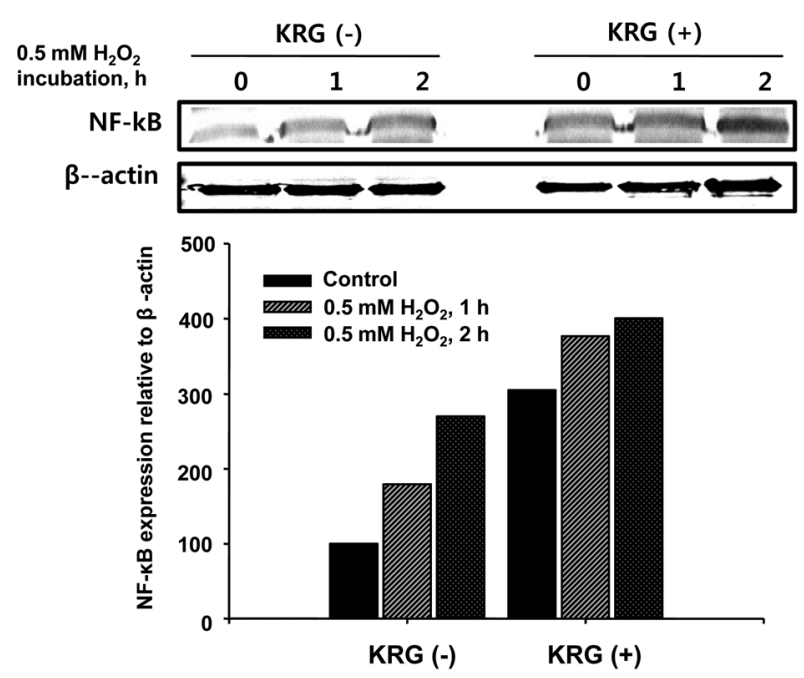

Fig. 4. Effect of Korean red ginseng (KRG) pre-treatment on NF-KB protein expression in $\mathrm{H}_{2} \mathrm{O}_{2}$-exposed $\mathrm{SK}-\mathrm{N}-\mathrm{SH}$ cells. SK-N-SH cells $\left(5 \times 10^{4}\right.$ cells $)$ were pre-treated with $1 \mathrm{mg} / \mathrm{mL} \mathrm{KRG}$ extract for 48 hours; cells were then washed with fresh media and exposed to $0.5 \mathrm{mM} \mathrm{H}_{2} \mathrm{O}_{2}$ for 1 or 2 hours. NF-KB levels were detected by Western blot analysis using an anti-NF-KB antibody.

\section{Effect of KRG on cyclooxygenase $\mathbf{2}$ gene expression after oxidative stress}

The inflammatory response to stress exposure can affect behavior, mood, memory, and cell survival [23]. Moreover, cells exposed to stress activate neutrophils and subsequently secrete myeloperoxidase, which is responsible for protein oxidation [24]. To determine whether the increased resistance to oxidative stress by $\mathrm{KRG}$ is due to repression of the cyclooxygenase (COX2) gene, COX-2 mRNA levels were examined by RTPCR. Results showed that COX-2 gene expression was not affected by KRG treatment alone (Fig. 5A). COX2 expression was induced after 30 minutes of exposure to $\mathrm{H}_{2} \mathrm{O}_{2}$, and remained induced over a 2 hour incubation with $\mathrm{H}_{2} \mathrm{O}_{2}$ (Fig. 5B). In contrast, KRG pre-treatment significantly repressed this induction of COX-2; levels of COX- 2 mRNA were $60 \%$ and $70 \%$ less in the cotreatment groups (at 1 hour and 2 hours, respectively), compared to cells that were exposed to $\mathrm{H}_{2} \mathrm{O}_{2}$ alone (Fig. $5 \mathrm{~B})$, demonstrating that $\mathrm{KRG}$ did not affect expression of COX-2 under normal conditions, but repressed expression only when the cells are exposed to oxidative stress.

Oxidative stress is associated with various diseases as well as aging [25]. Among the organs of the body, the brain contains large amounts of oxidizable substrates such as neurotransmitters and polyunsaturated fatty acids; thus, the brain is one of the organs most sensitive to oxidative stress [26]. The brain consumes oxygen constantly to catalyze metabolic processes that generate large amounts of energy; these processes generate reactive oxygen species, which can cause oxidative stress and concomitant neuronal damage and cell death [26]. 
A

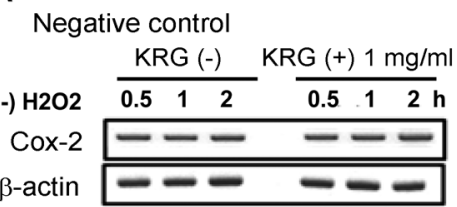

B

\begin{tabular}{|c|c|c|c|c|c|c|}
\hline \multirow[b]{2}{*}{ (+) $\mathrm{H} 2 \mathrm{O} 2$} & \multicolumn{3}{|c|}{ KRG (-) } & \multicolumn{3}{|c|}{$\mathrm{KRG}(+) 1 \mathrm{mg} / \mathrm{ml}$} \\
\hline & 0.5 & 1 & 2 & 0.5 & 1 & $2 \mathrm{~h}$ \\
\hline Cox-2 & - & - & - & - & - & - \\
\hline$\beta$-acti & - & - & - & - & - & - \\
\hline
\end{tabular}

Fig. 5. Effect of Korean red ginseng (KRG) pre-treatment on cyclooxygenase 2 (COX-2) gene expression levels in $\mathrm{H}_{2} \mathrm{O}_{2}$-exposed SK-N-SH cells. SK-N-SH cells $\left(1.5 \times 10^{6}\right.$ cells) were pre-treated with $1 \mathrm{mg} / \mathrm{mL} \mathrm{KRG}$ extract for 48 hours; cells were then washed with fresh media and exposed to $0.5 \mathrm{mM} \mathrm{H}_{2} \mathrm{O}_{2}$ for the time specified. RNA levels were determined by reverse-transcriptase PCR.

Therefore, prevention of oxidative stress in the brain is important for increasing quality of life and longevity. However, the mechanisms underlying neuronal cell death have not been clearly elucidated.

Stress causes production of reactive oxygen species, which subsequently induces cell death. A previous study has shown that cold swim stress induced an increase in serum lipid peroxide and nitrite/nitrate levels; these changes led to disruption of anti-oxidative responses and induction of NO production and neutrophil infiltration, and resulted in vacuolization and cell death in the rat liver [27]. Moreover, as the immobilization stress time was lengthened, expression levels of stress/cell death-related and muscle-specific genes were induced [28], and chronic immobilization stress induced cell death in rat testicular germ cells [29]. It has also been shown that once oxidative stress is induced, the balance of anti-oxidative responses is disrupted, and this imbalance leads to DNA damage, an increase in calcium and iron release from cells, damage of ion transport in membranes, and lipid peroxidation; the overall result is severely abnormal metabolism [30].

Our results show that oxidative stress can increase cell death and induce expression of pro-inflammatory genes. We demonstrate that pre-treatment of neuronal cells with KRG can reverse this process, probably by decreasing the expression of pro-apoptotic and proinflammatory genes (caspase-3 and COX-2, respectively) and increasing the expression of anti-apoptotic genes such as Bcl-2. However, how and why NF- $\mathrm{BB}$ expression is induced by KRG should be investigated further. These studies support the importance of further investigation into how KRG modulates signaling pathways that promote apoptosis and/or antiinflammatory activity.

\section{ACKNOWLEDGEMENTS}

This work was supported by the grant from the Korean Society of Ginseng funded by Korea Ginseng Corporation.

\section{REFERENCES}

1. Nam KY. The comparative understanding between red ginsengs and white ginsengs, processed ginsengs (Panax ginseng C.A. Meyer). J Ginseng Res 2005;29:1-18.

2. Filaretov AA, Bogdanova TS, Podvigina TT, Bodganov AI. Role of pituitary-adrenocortical system in body adaptation abilities. Exp Clin Endocrinol 1988;92:129-136.

3. Kim SH, Park KS, Chang MJ, Sung JH. Effects of Panax ginseng extract on exercise-induced oxidative stress. J Sports Med Phys Fitness 2005;45:178-182.

4. Voces J, Cabral de Oliveira AC, Prieto JG, Vila L, Perez AC, Duarte ID, Alvarez AI. Ginseng administration protects skeletal muscle from oxidative stress induced by acute exercise in rats. Braz J Med Biol Res 2004;37:18631871.

5. Chen JX, Li W, Zhao X, Yang JX. Effects of the Chinese traditional prescription Xiaoyaosan decoction on chronic immobilization stress-induced changes in behavior and brain BDNF, TrkB, and NT-3 in rats. Cell Mol Neurobiol 2008;28:745-755.

6. Rai D, Bhatia G, Sen T, Palit G. Anti-stress effects of Ginkgo biloba and Panax ginseng: a comparative study. J Pharmacol Sci 2003;93:458-464.

7. Lee SE, Lee SW, Bang JK, Yu YJ, Seong NS. Antioxidant activities of leaf, stem, and root of Panax ginseng C. A. Meyer. Korean J Med Crop Sci 2004;12:237-242.

8. Kim DH, Moon YS, Lee TH, Jung JS, Suh HW, Song DK. The inhibitory effect of ginseng saponins on the stressinduced plasma interleukin-6 level in mice. Neurosci Lett 2003;353:13-16.

9. Zhang QH, Wu CF, Duan L, Yang JY. Protective effects of total saponins from stem and leaf of Panax ginseng against cyclophosphamide-induced genotoxicity and apoptosis in mouse bone marrow cells and peripheral lymphocyte cells. Food Chem Toxicol 2008; 46:293-302.

10. Luo YM, Cheng XJ, Yuan WX. Effects of ginseng root saponins and ginsenoside $\mathrm{Rb} 1$ on immunity in cold water swim stress mice and rats. Zhongguo Yao Li Xue Bao 1993;14:401-404.

11. Choi SS, Lee JK, Suh HW. Effect of ginsenosides ad- 
ministered intrathecally on the antinociception induced by cold water swimming stress in the mouse. Biol Pharm Bull 2003;26:858-861.

12. Naval MV, Gomez-Serranillos MP, Carretero ME, Villar AM. Neuroprotective effect of a ginseng (Panax ginseng) root extract on astrocytes primary culture. J Ethnopharmacol 2007;112:262-270.

13. Lopez MV, Cuadrado MP, Ruiz-Poveda OM, Del Fresno AM, Accame ME. Neuroprotective effect of individual ginsenosides on astrocytes primary culture. Biochim Biophys Acta 2007;1770:1308-1316.

14. Tu LH, Ma J, Liu HP, Wang RR, Luo J. The neuroprotective effects of ginsenosides on calcineurin activity and tau phosphorylation in SY5Y cells. Cell Mol Neurobiol 2009;29:1257-1264.

15. Dang H, Chen Y, Liu X, Wang Q, Wang L, Jia W, Wang Y. Antidepressant effects of ginseng total saponins in the forced swimming test and chronic mild stress models of depression. Prog Neuropsychopharmacol Biol Psychiatry 2009;33:1417-1424.

16. Hwang YP, Jeong HG. Ginsenoside Rb1 protects against 6-hydroxydopamine-induced oxidative stress by increasing heme oxygenase-1 expression through an estrogen receptor-related PI3K/Akt/Nrf2-dependent pathway in human dopaminergic cells. Toxicol Appl Pharmacol 2010;242:18-28.

17. Radad K, Gille G, Moldzio R, Saito H, Rausch WD. Ginsenosides Rb1 and Rg1 effects on mesencephalic dopaminergic cells stressed with glutamate. Brain Res 2004;1021:41-53.

18. Kim S, Nah SY, Rhim H. Neuroprotective effects of ginseng saponins against L-type $\mathrm{Ca} 2+$ channel-mediated cell death in rat cortical neurons. Biochem Biophys Res Commun 2008;365:399-405.

19. Liao B, Newmark H, Zhou R. Neuroprotective effects of ginseng total saponin and ginsenosides $\mathrm{Rb} 1$ and $\mathrm{Rg} 1$ on spinal cord neurons in vitro. Exp Neurol 2002;173:224234.
20. Li N, Liu B, Dluzen DE, Jin Y. Protective effects of ginsenoside Rg2 against glutamate-induced neurotoxicity in PC12 cells. J Ethnopharmacol 2007;111:458-463.

21. Ye R, Li N, Han J, Kong X, Cao R, Rao Z, Zhao G. Neuroprotective effects of ginsenoside $\mathrm{Rd}$ against oxygenglucose deprivation in cultured hippocampal neurons. Neurosci Res 2009;64:306-310.

22. Smirnov IM, Bailey K, Flowers CH, Garrigues NW, Wesselius LJ. Effects of TNF-alpha and IL-1beta on iron metabolism by A549 cells and influence on cytotoxicity. Am J Physiol 1999;277:L257- L263.

23. Garcia-Bueno B, Caso JR, Leza JC. Stress as a neuroinflammatory condition in brain: damaging and protective mechanisms. Neurosci Biobehav Rev 2008;32:11361151.

24. Yazici C, Kose K, Caliş M, DemIr M, Kirnap M, Ates F. Increased advanced oxidation protein products in Behçet's disease: a new activity marker? Br J Dermatol 2004;151:105-111.

25. Liu J, Mori A. Stress, aging, and brain oxidative damage. Neurochem Res 1999;24:1479-1497.

26. Konishi T. Brain oxidative stress as basic target of antioxidant traditional oriental medicines. Neurochem Res 2009;34:711-716.

27. Ohta Y, Chiba S, Tada M, Imai Y, Kitagawa A. Development of oxidative stress and cell damage in the liver of rats with water-immersion restraint stress. Redox Rep 2007;12:139-147.

28. Kim JW, Kwon OY, Kim MH. Differentially expressed genes and morphological changes during lengthened immobilization in rat soleus muscle. Differentiation 2007;75:147-157.

29. Sasagawa I, Yazawa H, Suzuki Y, Nakada T. Stress and testicular germ cell apoptosis. Arch Androl 2001;47:211216.

30. Taylor NL, Millar AH. Oxidative stress and plant mitochondria. Methods Mol Biol 2007;372:389-403. 